\title{
Anti-inflammatory effect of rosiglitazone is not reflected in expression of NF $\kappa$ B-related genes in peripheral blood mononuclear cells of patients with type 2 diabetes mellitus Marjolijn CE Bragt ${ }^{1,2}$, Jogchum Plat ${ }^{2}$, Marco Mensink², Patrick Schrauwen*2 and Ronald P Mensink ${ }^{1,2}$
}

Address: ${ }^{1}$ Nutrigenomics Consortium, Top Institute Food and Nutrition, PO BOX 557, 6700 AN Wageningen, The Netherlands and ${ }^{2}$ NUTRIM School for Nutrition, Toxicology and Metabolism, Department of Human Biology, Maastricht University Medical Centre+, PO Box 616, 6200 MD Maastricht, The Netherlands

Email: Marjolijn CE Bragt - m.bragt@hb.unimaas.nl; Jogchum Plat - j.plat@hb.unimaas.nl; Marco Mensink - marco.mensink@wur.nl; Patrick Schrauwen* - p.schrauwen@hb.unimaas.nl; Ronald P Mensink - r.mensink@hb.unimaas.nl

* Corresponding author

Published: 25 February 2009

BMC Endocrine Disorders 2009, 9:8 doi:10.1186/1472-6823-9-8

This article is available from: http://www.biomedcentral.com/I472-6823/9/8

C 2009 Bragt et al; licensee BioMed Central Ltd.

This is an Open Access article distributed under the terms of the Creative Commons Attribution License (http://creativecommons.org/licenses/by/2.0), which permits unrestricted use, distribution, and reproduction in any medium, provided the original work is properly cited.
Received: I October 2008

Accepted: 25 February 2009

\begin{abstract}
Background: Rosiglitazone not only improves insulin-sensitivity, but also exerts anti-inflammatory effects. We have now examined in type 2 diabetic patients if these effects are reflected by changes in mRNA expression in peripheral blood mononuclear cells (PBMCs) to see if these cells can be used to study these anti-inflammatory effects at the molecular level in vivo.
\end{abstract}

Method: Eleven obese type 2 diabetic patients received rosiglitazone $(2 \times 4 \mathrm{mg} / \mathrm{d})$ for 8 weeks. Fasting blood samples were obtained before and after treatment. Ten obese control subjects served as reference group. The expression of NFKB-related genes and PPAR $\gamma$ target genes in PBMCs, plasma TNF $\alpha$, IL6, MCPI and hsCRP concentrations were measured. In addition, blood samples were obtained after a hyperinsulinemic-euglycemic clamp.

Results: Rosiglitazone reduced plasma MCPI and hsCRP concentrations in diabetic patients (-9.5 $\pm 5.3 \mathrm{pg} / \mathrm{mL}, p=0.043$ and $-1.1 \pm 0.3 \mathrm{mg} / \mathrm{L} p=0.003$ ), respectively). For hsCRP, the concentration became comparable with the non-diabetic reference group. However, of the $84 \mathrm{NFKB}$-related genes that were measured in PBMCs from type 2 diabetic subjects, only RELA, SLC20AI, INF $\gamma$ and ILIRI changed significantly $(p<0.05)$. In addition, PPAR $\gamma$ and its target genes (CD36 and LPL) did not change. During the clamp, insulin reduced plasma MCPI concentration in the diabetic and reference groups $(-9.1 \pm 1.8 \%, p=0.00 \mathrm{I}$ and $-1 \mathrm{I} . \mathrm{I} \pm 4.1 \%, p=0.023$, respectively) and increased IL6 concentration in the reference group only $(23.5 \pm 9.0 \%, p=0.028)$.

Conclusion: In type 2 diabetic patients, the anti-inflammatory effect of rosiglitazone is not reflected by changes in NFKB and PPAR $\gamma$ target genes in PBMCs in vivo. Furthermore, our results do not support that high insulin concentrations contribute to the pro-inflammatory profile in type 2 diabetic patients. 


\section{Background}

Rosiglitazone, an agonist for the nuclear receptor peroxisome proliferator-activated receptor gamma (PPAR $\gamma)$, is a widely used drug for the treatment of type 2 diabetes mellitus. It belongs to the group of thiazolidinediones (TZD) and increases insulin sensitivity of peripheral tissues. In addition, there is evidence that rosiglitazone has antiinflammatory effects [1-3]. It has been postulated that rosiglitazone exerts its anti-inflammatory effect through inhibition of the transcription factor nuclear factor $\kappa B(\mathrm{NF \kappa B})$ pathway [1]. Normally, NFkB is bound in the cytosol to its

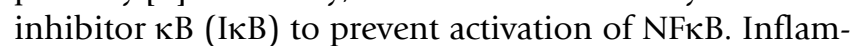
matory signals can cause phosphorylation of I $\mathrm{B}$, thereby releasing and activating $\mathrm{NF \kappa B}$, followed by translocation of $N F \kappa B$ to the nucleus and activation of genes involved in the pro-inflammatory response, such as TNF $\alpha$ and matrix metalloproteinases [4]. To further understand in humans the in vivo (anti-inflammatory) effects of rosiglitazone treatment at the molecular level, it would be advantageous that Peripheral Blood Mononuclear Cells (PBMCs) could be used. These cells are readily accessible in humans compared to the relatively inaccessible target tissues of PPAR $\gamma$ ligands, namely adipose tissue and liver [5]. It has already been demonstrated that monocytes respond to PPAR $\gamma$ ligands by reducing the expression of inflammatory cytokines ex vivo, such as TNF $\alpha$, IL-6 and IL1b [6]. In addition, Mohanty et al. [3] have shown that rosiglitazone inhibits the binding of NFKB to DNA in the nucleus of PBMCs from obese and obese diabetic patients. This was accompanied by an anti-inflammatory effect, as indicated by reduced plasma hsCRP and MCP-1 concentrations [3]. However, it is not known if rosiglitazone's anti-inflammatory effect changes the transcription of NFKB related genes in PBMCs in vivo. Therefore, the first aim of our study was to examine if anti-inflammatory properties of rosiglitazone are reflected in changes in expression of genes involved in the NFאB signaling pathway in PBMCs. Furthermore, the role of an increased insulin concentration in low-grade systemic inflammation, as often seen in type 2 diabetic patients, is not completely understood [7]. Therefore, the second aim of this study was to examine plasma inflammatory markers in the fasted (hyperglycaemic) state and during hyperinsulinemia using a hyperinsulinemic-euglycemic clamp.

\section{Methods \\ Subjects}

Twelve middle-aged obese men with well-controlled type 2 diabetes mellitus participated in this study. Due to extreme changes in serum cholesterol concentrations and gene expression profiles, one subject was excluded from the statistical analyses. The characteristics of the 11 remaining (age, $62 \pm 5 \mathrm{y}$; body mass index (BMI), $31 \pm 3$ $\mathrm{kg} / \mathrm{m}^{2}$ ) type 2 diabetic subjects and 10 BMI and age matched normoglycemic controls (age, $57 \pm 8$ y; BMI, 30 $\pm 4 \mathrm{~kg} / \mathrm{m}^{2}$ ) are shown in table 1 . Type 2 diabetes mellitus was diagnosed at least 1 year before the study, and most patients were treated with sulphonylurea $(n=3)$ or metformin $(n=5)$ or both $(n=1)$ as anti-diabetic medication. Control subjects had normal glucose homeostasis, as determined with a standard oral glucose tolerance test, and had no family history of diabetes. The Medical Ethical Review Board of Maastricht University had approved the study and written, informed consent was obtained from all volunteers.

\section{Study design}

Details of this study have been described previously $[8,9]$. In short, diabetic patients stopped any anti-diabetic medication 14 days before the start of the study. Subjects were asked not to participate in (exhaustive) physical activity the last three days preceeding the measurements, and to consume a diet according to the Dutch guidelines for a healthy diet. After a baseline hyperinsulinemic-euglycemic clamp, diabetic patients were treated with rosiglitazone (Avandia ${ }^{\circledast}$, GlaxoSmithKline, Zeist, the

Table I: BMI and plasma parameters of type 2 diabetic patients before and after rosiglitazone treatment and of non-diabetic controls.

\begin{tabular}{|c|c|c|c|}
\hline & \multicolumn{2}{|c|}{ Diabetic patients $(n=I I)$} & \multirow[t]{2}{*}{ Controls $(n=10)$} \\
\hline & Before treatment & After treatment & \\
\hline BMI $\left(\mathrm{kg} / \mathrm{m}^{2}\right)$ & $30 \pm 1.0$ & $31 \pm 1.0$ & $31 \pm 1.3$ \\
\hline Glucose (mmol/L) & $9.2 \pm 0.5^{\mathrm{a}}$ & $8.1 \pm 0.5^{b, c}$ & $5.8 \pm 0.1$ \\
\hline Insulin (mU/L) & $24.1 \pm 3.1^{a}$ & $17.2 \pm 1.7^{b, c}$ & $12.3 \pm 0.9$ \\
\hline GIR ( $\mu \mathrm{mol} / \mathrm{kg} / \mathrm{min})$ & $12.8 \pm 1.3^{a}$ & $20.6 \pm 1.7^{b}$ & $24.6 \pm 2.4$ \\
\hline Total cholesterol (mmol/L) & $5.4 \pm 0.3$ & $5.7 \pm 0.4$ & $5.2 \pm 0.3$ \\
\hline LDL cholesterol (mmol/L) & $3.5 \pm 0.2$ & $3.8 \pm 0.4$ & $3.4 \pm 0.3$ \\
\hline HDL cholesterol (mmol/L) & $0.93 \pm 0.1$ & $1.10 \pm 0.1^{b}$ & $1.14 \pm 0.1$ \\
\hline $\mathrm{TCH} / \mathrm{HDL}$ ratio & $6.9 \pm 1.1$ & $5.5 \pm 1.0$ & $5.5 \pm 1.1$ \\
\hline Triglycerides (mmol/L) & $2.0 \pm 0.3$ & $1.5 \pm 0.2^{b}$ & $\mathrm{I} .5 \pm 0.4$ \\
\hline $\mathrm{FFA}(\mathrm{mmol} / \mathrm{L})$ & $509 \pm 47$ & $400 \pm 37 b$ & $513 \pm 45.6$ \\
\hline
\end{tabular}

a Significantly different $(P<0.05)$ between diabetic patients and non-diabetic controls

b Significant effect $(P<0.05)$ of rosiglitazone treatment in diabetic patients

c Significantly different $(P<0.05)$ between diabetic patients after rosiglitazone treatment and non-diabetic controls 
Netherlands), $8 \mathrm{mg} /$ day $(2 \times 4 \mathrm{mg})$ for 8 weeks. After rosiglitazone treatment, subjects underwent a second clamp. Blood samples were drawn before and after the clamp, thereby providing fasting and insulin-stimulated blood samples before and after rosiglitazone treatment.

The non-diabetic patients served as baseline controls to the diabetic patients. They also underwent a hyperinsulinemic-euglycemic clamp, but were not treated with rosiglitazone.

\section{Hyperinsulinemic-euglycemic clamp}

After an overnight fast, subjects came to the laboratory at $8 \mathrm{AM}$. A cannula was inserted into each antecubital vein for the infusion of tracer, insulin and glucose. A third cannula was inserted retrogradely into a superficial dorsal hand vein for arterialized blood sampling. After taking fasting blood samples, a primed constant infusion of $[6,6]-{ }^{2} \mathrm{H}_{2}$-glucose was initiated $(0.04 \mathrm{mg} / \mathrm{kg} \cdot \mathrm{min})$ for 300 minutes. At $\mathrm{t}=120 \mathrm{~min}$, a 3-hour primed constant infusion of insulin (Actrapid, Novo Nordisk, Bagsvaerd, Denmark) was started $\left(40 \mathrm{mU} / \mathrm{m}^{2} \cdot \mathrm{min}\right)$, and glucose was clamped by a variable co-infusion of $20 \%$ glucose with tracer added. Blood samples taken at $\mathrm{t}=0 \mathrm{~min}$ and $\mathrm{t}=300$ min were used for further analysis.

\section{Plasma measurements}

EDTA plasma was obtained by 10 minutes of centrifugation at $3000 \mathrm{rpm}$ immediately after sampling, and stored at $-80^{\circ} \mathrm{C}$ for later analysis. Concentrations of total cholesterol (ABX Diagnostics, Montpelier, France), HDL cholesterol (precipitation method; Roche Diagnostics Corporation, Indianapolis, IN), and triglycerides corrected for free glycerol (Sigma-Aldrich Chemie, Steinheim, Germany) were analysed enzymatically. Serum LDL cholesterol concentrations were calculated by using the formula of Friedewald et al. [10]. Insulin concentrations were measured using a RIA (Linco Research. St. Charles, MO, USA). Free fatty acids (FFA) were determined using the Wako Nefa C test kit (Wako Chemicals, Neuss, Germany) and plasma glucose was determined by using the hexokinase method (LaRoche, Basel, Switzerland). The glucose infusion rate (GIR) was used as a measure of insulin sensitivity. For the inflammation markers, high sensitive CRP (hsCRP) was measured on Cobas Mira with a commercial available kit (Kamiya Biomedical Company, Seattle, WA, USA) and TNF $\alpha$, IL6 and MCP1 were measured with an ELISA kit from R\&D systems. All samples from one subject were analysed in the same analytical run. Samples were corrected for plasma albumin concentrations to correct for changes in blood volume due to fluid infusion during the hyperinsulinemic-euglycemic clamp [11].

\section{PBMC isolation and total RNA isolation}

PBMCs were isolated from an EDTA anti-coagulated peripheral fasted blood sample of diabetic patients only, directly after blood sampling through gradient centrifugation using lymphoprep (Nycomed, Oslo, Norway) according to the instructions from the manufacturer. The obtained PBMCs were immediately lysed and homogenised in $1.5 \mathrm{ml}$ Trizol (Invitrogen Life Technologies, Breda, The Netherlands) for RNA stabilisation and subsequent RNA isolation according a standardized protocol as described by the manufacturer. Next, RNA was purified using the RNeasy mini kit (Qiagen Benelux B.V., Venlo, the Netherlands) followed by dissolving the RNA in RNAse and DNAse free water (Invitrogen Life Technologies, Breda, The Netherlands). RNA purity was measured on the NanoDrop 1000 (NanoDrop Technologies, Wilmington, DE, USA), and considered suitable for further processing at 260/280 and 260/230 ratios of $>1.7$. Integrity was evaluated using the BioAnalyzer (Agilent, Palo Alto CA, USA) and considered to be intact with an RNA integrity number $>7.0$.

\section{Real time PCR}

cDNA was synthesised using the ReactionReady ${ }^{\mathrm{TM}}$ First Strand cDNA Synthesis Kit (SuperArray Bioscience corporation, Frederick, MD, USA). The total amount of RNA used in the reaction varied from $800 \mathrm{ng}$ to $1 \mu \mathrm{g}$. Equal amounts of RNA were used for samples before and after treatment of the same subject.

Gene expression of NFKB pathway focussed genes was analysed using NFKB RT2 Profiler PCR arrays, according to the manufacturer's instructions (SuperArray Bioscience Corporation, Frederick, MD, USA). The PCR array consisted of a 96-well plate including primer sets of $84 \mathrm{NFKB}$ related genes (see additional file 1), plus 5 housekeeping genes and 2 negative controls. The primer sets were optimised for real time detection using $\mathrm{RT}^{2}$ Real Time ${ }^{\mathrm{TM}}$ SYBR Green PCR master mix (SuperArray Bioscience Corporation, Frederick, MD, USA). In addition, the relative expression levels of PPAR $\gamma, \mathrm{CD} 36$ and LPL, were also determined with real time PCR, using assays-on-demand and Taqman Universal Mastermix (Applied Biosystems, Foster City, CA, USA). All gene expression analyses were performed on the ABI PISM 7000 system (Applied Biosystems, Foster City, CA, USA).

\section{Data analysis of real time PCR data}

The No Template Control tested for DNA contamination in the PCR system and the No Reverse Transcription Control tested for contamination of the original RNA with genomic DNA. Those threshold cycles were above 35, which indicates that there was no contamination. The average $C_{t}$ values of the housekeeping genes, $\beta$-actin and 18 srRNA, were used for normalisation of each individual 
sample. To express the difference in expression before and after rosiglitazone treatment in diabetic patients, the $\Delta \Delta \mathrm{C}_{\mathrm{t}}$ value was calculated for each gene according to the comparative Ct method, and was used for statistical analysis.

\section{Statistics}

Fasting plasma parameters are presented as mean \pm SEM. Gene expression levels were not normally distributed and are therefore expressed as median $\Delta \Delta \mathrm{C}_{\mathrm{t}}$ values together with corresponding ranges. An independent Student's ttest was used to compare diabetic patients before or after rosiglitazone with control subjects. Results of plasma parameters before and after rosiglitazone treatment in type 2 diabetic patients were analysed using a paired Student's t-test. The effect of rosiglitazone on gene expression levels in type 2 diabetic patients was analysed with the non-parametric Wilcoxon signed rank test. Changes (\%) in plasma parameters during the hyperinsulinemic-euglycemic clamp (T0 vs. T300) were tested with a one sample t-test. In addition, using the Student's t-test, the changes in plasma parameters induced by the hyperinsulinemic-euglycemic clamp before rosiglitazone treatment were compared to the clamp-induced changes after rosiglitazone treatment.

All statistical analyses were performed with SPSS 14.0 for Windows (SPSS Inc., Chicago, IL, USA).

\section{Results}

\section{Body weight}

There was no difference in body weight between diabetic patients and the BMI-matched controls $(94.3 \pm 4.1 \mathrm{~kg}$ and $92.7 \pm 4.1 \mathrm{~kg}$, respectively $(p=0.778))$. Rosiglitazone treatment resulted in a slight, but non-significant increase in body weight during the 8 weeks follow-up period in the diabetic patients $(1.3 \pm 1.0 \mathrm{~kg}, p=0.21)$.

\section{Plasma glucose and insulin concentrations and insulin sensitivity}

As expected, diabetic patients were less insulin-sensitive and had higher fasting plasma glucose and insulin concentrations compared with non-diabetic controls (Table 1). Fasting glucose and insulin were significantly decreased in the diabetic patients after rosiglitazone treatment $(-1.0 \pm 0.5 \mathrm{mmol} / \mathrm{L}, p=0.044)$ and $(-6.9 \pm 2.3 \mathrm{mU} /$ $\mathrm{L}, p=0.013$, respectively), while insulin sensitivity increased (change in GIR: $+7.8 \pm 1.9 \mu \mathrm{mol} / \mathrm{kg} / \mathrm{min}, p=$ 0.002) (Table 1).

\section{Plasma lipid concentrations}

As shown in Table 1, there were no significant differences in plasma total cholesterol, LDL cholesterol, HDL cholesterol, TCH/HDL ratio, triglycerides and free fatty acids (FFA) between diabetic patients and non-diabetic controls. Fasting HDL cholesterol increased significantly
$(+0.21 \pm 0.07 \mathrm{mmol} / \mathrm{L}, p=0.013)$, while triglyceride and FFA concentrations decreased $(-0.48 \pm 0.21 \mathrm{mmol} / \mathrm{L}, p=$ 0.042 and $-109 \pm 38 \mathrm{mmol} / \mathrm{L}, p=0.018$ respectively) upon rosiglitazone treatment in diabetic patients. Total cholesterol and LDL cholesterol concentrations were not significantly affected by rosiglitazone treatment $(+0.30 \pm$ $0.20 \mathrm{mmol} / \mathrm{L}, p=0.152$ and $+0.30 \pm 0.20 \mathrm{mmol} / \mathrm{L}, p=$ 0.160 , respectively). The $\mathrm{TCH} / \mathrm{HDL}$ ratio tended to improve after treatment $(-1.3 \pm 0.7)$, but this did not reach statistically significance $(p=0.09)$.

\section{Plasma hsCRP, TNF $\alpha$, IL6 and MCPI concentrations}

As shown in figure 1, the basal plasma concentration of hsCRP in the diabetic patients was $2.2 \pm 0.4 \mathrm{mg} / \mathrm{L}$, which was significantly higher than that of the non-diabetic controls $(1.0 \pm 0.2 \mathrm{mg} / \mathrm{L}, p=0.027)$. There were no differences in TNFa, IL6 and MCP1 concentrations between diabetic patients and control subjects. As a result of rosiglitazone treatment, basal hsCRP and MCP1 concentrations significantly decreased $(-1.1 \pm 0.3 \mathrm{mg} / \mathrm{L}, p=0.003$ and $9.5 \pm 5.3 \mathrm{pg} / \mathrm{mL}, p=0.043$, respectively) and, paradoxically, TNF $\alpha$ concentrations increased $(+0.22 \pm 0.1 \mathrm{pg} / \mathrm{mL}$, $p=0.037)$ in type 2 diabetic patients. After rosiglitazone treatment, hsCRP $(1.0 \pm 0.16 \mathrm{mg} / \mathrm{L})$ and MCP1 concentrations $(132 \pm 7 \mathrm{pg} / \mathrm{mL})$ in diabetic patients were comparable with those measured in non-diabetic controls.

\section{Expression of PPAR $\gamma$, PPAR $\gamma$ responsive genes and NF $K B$ related genes}

Of the 84 genes measured, 75 were detectable in PBMCs and only the expression of genes encoding for IFN $\gamma$ (interferon gamma), IL1R1 (interleukin 1 receptor 1), RELB (Vrel reticuloendotheliosis viral oncogene homolog $\mathrm{B}$, nuclear factor of kappa light polypeptide gene enhancer in B-cells 3 (avian)) and SLC20A1 (solute carrier family 20 (phosphate transporter) member 1) changed significantly in the diabetic patients upon rosiglitazone treatment (table 2).

The expression level of PPAR $\gamma$ itself was not changed by its ligand rosiglitazone. Also expression levels of CD36 (thrombospondin receptor) and LPL (lipoprotein lipase), which are known PPAR $\gamma$ target genes [12-14], did not change (Table 2).

\section{Changes in plasma parameters during the clamp}

Before rosiglitazone treatment, plasma albumin concentrations were $38.1 \pm 0.6 \mathrm{~g} / \mathrm{L}$ before the clamp and $36.8 \pm$ $0.5 \mathrm{~g} / \mathrm{L}$ after the clamp $(p=0.005)$. These concentrations were comparable after rosiglitazone treatment. For the control subjects, these values were before and after the clamp respectively $38.7 \pm 0.6 \mathrm{~g} / \mathrm{L}$ and $36.4 \pm 0.7 \mathrm{~g} / \mathrm{L}(p<$ 0.001 ). The observed reductions in plasma albumin concentration indicate that due to the glucose infusion, the plasma volume had changed during the clamp. Therefore, 

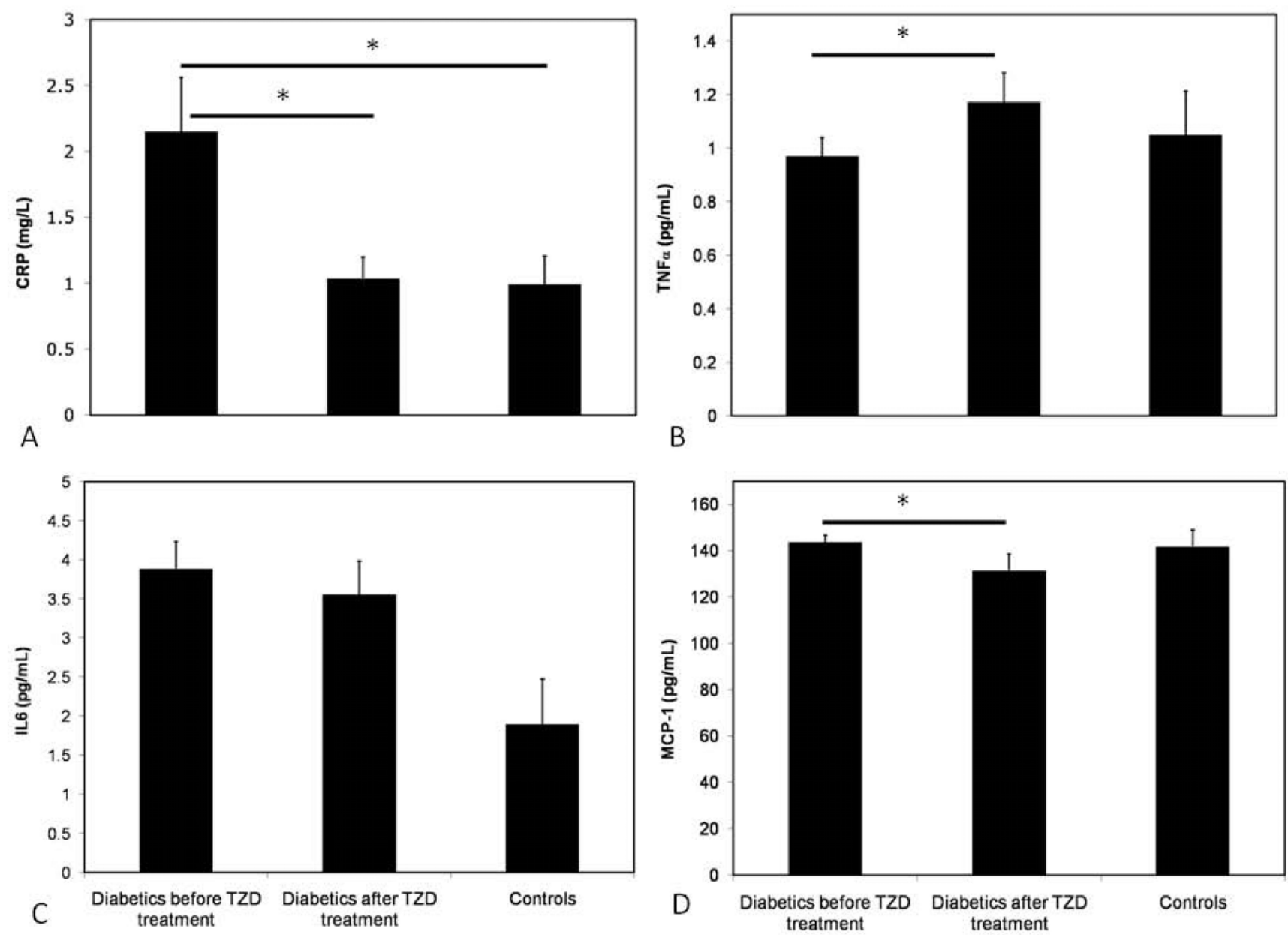

Figure I

Concentrations of plasma inflammation markers in controls and in diabetics before and after rosiglitazone treatment. Baseline concentrations of plasma inflammatory markers, A) hsCRP, B) TNF $\alpha$, C) IL6 and D) MCPI, in type 2 diabetic and control subjects and levels after rosiglitazone treatment in type 2 diabetic patients. $*=p$-value $<0.05$.

levels of the plasma parameters were related to those of albumin. It is known that plasma albumin concentrations are stable during the day [11].

Before treatment, serum total, LDL, and HDL cholesterol levels did not change in response to insulin during the hyperinsulinemic-euglycemic clamp in both type 2 diabetic patients and control subjects (Table 3 ). Triglycerides levels decreased in control subjects $(-16.7 \pm 4,5 \%, p=$ $0.007)$ and also in diabetic patients after rosiglitazone treatment $(-14.3 \pm 5.5 \%, p=0.027)$. FFA levels decreased significantly in type 2 diabetic patients $(-58.9 \pm 3.4 \%, p<$ $0.001)$ in response to insulin. In control subjects the reduction in FFA was even more pronounced $(-80.1 \pm$ $2.6 \%, p<0.001)$. Rosiglitazone improved the insulininduced decrease in FFA (from $-58.9 \pm 3.4 \%$ to $-65.0 \pm$ $4.1 \%, p=0.045)$.
Insulin significantly decreased MCP1 levels in type 2 diabetic patients before rosiglitazone treatment $(-9.1 \pm 1.8 \%$, $p=0.001)$ and control subjects $(-11.1 \pm 4.1 \%, p=0.023)$ (table 3). Control subjects also showed a significant increase in IL6 levels $(23.5 \pm 9.0 \%, p=0.028)$ Changes in TNF $\alpha$ levels upon insulin stimulation differed significantly before and after rosiglitazone treatment in diabetic patients. Levels of $\mathrm{TNF} \alpha$ increased during the clamp before rosiglitazone treatment $(+12.0 \pm 6.6 \%)$, but decreased after rosiglitazone treatment $(-9.1 \pm 7.9 \%, p=$ $0.006)$.

\section{Discussion}

In this study, 8 weeks of rosiglitazone treatment $(2 \times 4$ $\mathrm{mg} / \mathrm{d}$ ) not only improved insulin sensitivity and plasma lipids, but also lowered fasting plasma concentrations of hsCRP and MCP1. After rosiglitazone, fasting concentra- 
Table 2: Effect of rosiglitazone treatment on expression levels $\left(\Delta C_{t}\right)$ of PPAR $\gamma$, PPAR $\gamma$ responsive genes and $N F \kappa B$ related genes in type 2 diabetic patients 1,2

\begin{tabular}{|c|c|c|}
\hline Gene & $\Delta \Delta C_{t}$ (after - before treatment) & $p$-value ${ }^{3}$ \\
\hline PPAR $\gamma$ & $0.31(-0.70-1.29)$ & 0.213 \\
\hline CD36 & $0.37(-0.93-0.90)$ & 0.248 \\
\hline LPL & $-0.39(-0.90-1.26)$ & 0.248 \\
\hline $\mathrm{INF} \gamma$ & $-0.53(-3.04-0.62)$ & 0.045 \\
\hline ILIRI & $0.37(-1.16-1.51)$ & 0.041 \\
\hline RELB & $0.31(-0.23-2.27)$ & 0.016 \\
\hline SLC20AI & $0.41(-1.03-1.93)$ & 0.033 \\
\hline
\end{tabular}

I The expression of 84 genes related to $N F \kappa B$ was profiles using the $\mathrm{RT}^{2}$ Profiler $^{\mathrm{TM}}$ PCR Array; $\mathrm{n}=1 \mathrm{I}$

2 Values are reported as $\Delta \Delta C_{t}$ values and presented as medians with ranges. A negative $\Delta \Delta C_{t}$ value corresponds with an upregulation and a positive $\Delta \Delta \mathrm{C}_{\mathrm{t}}$ value with a downregulation of the gene after rosiglitazone treatment.

3 Gene expression levels ( $\Delta \mathrm{C}_{\mathrm{t}}$ values) were analysed with the nonparametric Wilcoxon signed rank test. Differences were considered significant at a $p$-value $<0.05$

tions of hsCRP and MCP1 in diabetic patients were even comparable to those of non-diabetic controls. These antiinflammatory changes were not reflected in the expression of NFkB-related genes in PBMCs.

Reductions in fasting triglyceride concentrations have been reported for other TZDs, such as pioglitazone, troglitazone and darglitazone. We have now shown that these results can be extended to rosiglitazone. Furthermore, FFA concentrations were also reduced after rosiglitazone treatment. These reductions may be explained by an increased clearance of TG and FFA, as shown by Dhindsa et al. [15]. Rosiglitazone treatment further significantly increased serum HDL cholesterol concentrations and total cholesterol and LDL cholesterol tended to increase Generally, the effects of rosiglitazone on serum lipid concentrations were comparable to those of other TZDs [16].

Rosiglitazone treatment in type 2 diabetic patients decreased hsCRP and MCP1 concentrations, indicating a reduced inflammatory state. Mohanty et al. also observed a significant reduction in MCP1 and hsCRP concentrations after 6 weeks of rosiglitazone treatment $(4 \mathrm{mg} / \mathrm{d})$ in non-diabetic obese subjects and obese diabetic patients [3]. In accordance with previous studies $[2,17,18]$, we did not observe an effect of rosiglitazone on plasma IL6 concentrations. The increase we observed in TNF $\alpha$ concentrations is unexpected, although studies on the effects of TZDs on plasma TNF $\alpha$ concentrations are inconsistent. Some studies have shown that plasma concentrations of this cytokine are increased in subjects with insulin resistance or type 2 diabetes $[19,20]$. A number of other studies, however, showed reduced TNF $\alpha$ concentrations [21,22] after rosiglitazone treatment in type 2 diabetic patients, whereas others found no effect [18]. In line with our observations, Goldstein et al. [23] showed that TNFa concentrations were significantly increased when rosiglitazone was added to metformin treatment in type 2 diabetic patients. Due to these inconsistent results, a clear explanation is lacking.

Despite the rosiglitazone-induced reductions in fasting plasma CRP and MCP1, which are under control of NFKB $[24,25]$, expression of NFKB-related genes in PBMCs hardly changed upon rosiglitazone treatment. Of the 75 detectable NFкB-related genes in PBMCs, only 4 genes were significantly altered. The gene encoding for interferon gamma (INF $\gamma$ ) was significantly upregulated, whereas ILR1, RELB and SLC20A1 were significantly downregulated by rosiglitazone treatment. These changes would indicate an inhibition of the NFKB signalling cas-

Table 3: Relative changes in plasma parameters upon insulin-stimulation during the hyperinsulinemic-euglycemic clamp

\begin{tabular}{|c|c|c|c|}
\hline & \multicolumn{2}{|c|}{ Diabetic patients $(\mathrm{n}=\mathrm{II})$} & \multirow[t]{2}{*}{ Controls $(n=10)$} \\
\hline & Before treatment & After treatment & \\
\hline Albumin (\%) & $-3.4 \pm 0.9 \#$ & $-3.1 \pm 1 . I^{\#}$ & $-6.0 \pm 0.8^{\#}$ \\
\hline Total cholesterol (\%) & $0.4 \pm 0.8$ & $-1.7 \pm 1.4$ & $0.4 \pm 0.7$ \\
\hline LDL cholesterol (\%) & $2.5 \pm 2.1$ & $-0.5 \pm 1.3$ & $2.3 \pm 1.1$ \\
\hline HDL cholesterol (\%) & $1.3 \pm 2.7$ & $0.8 \pm 1.6$ & $2.7 \pm 1.3$ \\
\hline Triglycerides (\%) & $-5.2 \pm 6.4$ & $-14.3 \pm 5.5^{\mathrm{a}, \mathrm{c}}$ & $-16.7 \pm 4.5^{\mathrm{a}}$ \\
\hline FFA (\%) & $-58.9 \pm 3.4^{a, b}$ & $-65.0 \pm 4 . I^{a, c}$ & $-80.1 \pm 2.6^{a}$ \\
\hline hsCRP (\%) & $-4.7 \pm 2.7$ & $-4.9 \pm 2.4$ & $5.5 \pm 4.5$ \\
\hline TNF $\alpha(\%)$ & $12.0 \pm 6.6$ & $-9.1 \pm 7.9 c$ & $12.1 \pm 14.2$ \\
\hline IL6 (\%) & $13.7 \pm 6.7$ & $16.4 \pm 7.9$ & $23.5 \pm 9.0^{\mathrm{a}}$ \\
\hline MCPI (\%) & $-9.1 \pm 1.8^{a}$ & $-3.7 \pm 4.0$ & $-11.1 \pm 4.1^{\mathrm{a}}$ \\
\hline
\end{tabular}

\# Plasma albumin changed $(p<0.05)$ during the clamp because of increase in blood volume due to fluid infusion. Therefore, all plasma parameters are corrected for changes in plasma albumin concentration and presented as mean \pm SEM

a Significant change $(P<0.05)$ in response to insulin

b Significant difference between type 2 diabetic patients and BMI-matched controls in response to insulin

c Significant change $(P<0.05)$ effect of rosiglitazone treatment on the response to insulin in type 2 diabetic patients 
cade [4,26-28]. The significant reduction in MCP1 and hsCRP concentrations after 6 weeks of rosiglitazone treatment $(4 \mathrm{mg} / \mathrm{d})$ in non-diabetic obese subjects and obese diabetic patients as described by Mohanty et al., was accompanied by a significant fall in intranuclear NFKB levels in PBMCs [3]. This suggests a direct interference of PPAR $\gamma$ in the binding of NFKB to the promotor regions of proinflammatory genes. However, these reduced intranuclear NFkB levels were not accompanied by a changed expression of the NFkB-related genes IkB and p65 (REL A) after rosiglitazone treatment $[3,29]$. For troglitazone, another PPAR $\gamma$ agonist, it has also been demonstrated that intranuclear and cellular levels of NFKB were decreased in mononuclear cells of obese subjects [30]. Unfortunately, these studies did not examine if the fall in intranuclear $\mathrm{NF \kappa B}$ levels was accompanied by a reduced expression of inflammatory NFkB target genes. In our study, the lack of effect on NFkB related genes by rosiglitazone in PBMCs suggests that PBMCs are insensitive to rosiglitazone.

To further substantiate whether PBMCs were non-responsive to rosiglitazone treatment, we evaluated if rosiglitazone influenced gene expression of specific PPAR $\gamma$ dependent genes in PBMCs in vivo, i.e., PPAR $\gamma$ itself, CD36 and lipoprotein lipase (LPL). In vitro and ex vivo studies have shown that expression of CD36 [31,32] and LPL [33] in macrophages increased after activation of PPAR $\gamma$. In our study, however, the in vivo expression of PPAR $\gamma, \mathrm{CD} 36$ and LPL in PBMCs was not altered by rosiglitazone treatment, which suggests that PBMCs are non-responsive to rosiglitazone. In contrast to most other studies, we used PBMCs, a mixed population of white blood cells, and studied the in vivo effects. Most studies that did observe anti-inflammatory effects of rosiglitazone focussed on in vitro effects in a specific subpopulation of blood cells, namely monocytes or macrophages. These studies showed an increased expression of PPAR $\gamma$ and PPAR $\gamma$ responsive genes when these cells were cultured ex vivo or in vitro, and/or were given extra cytokine stimulation $[31,34,35]$. In vivo, Bouhlel et al. [34] showed a significant upregulation of PPAR $\gamma$ expression in PBMCs of subjects after 2 months of $45 \mathrm{mg} /$ day pioglitazone (TZD) treatment in patients with severe atherosclerosis, although expression of the PPAR $\gamma$ dependent genes, CD136 and mannose receptor, did not change. Combining these finding with our results suggests that gene expression profiles in PBMCs are not suitable to use as a biomarker to study in vivo the effects of rosiglitazone intervention at a molecular level. Whether specific subpopulations of cells within PBMCs are suitable, warrant further investigation. In this respect, study of monocytes, preferably isolated from blood via for example cell sorter techniques, warrants attention as especially the monocytes play an important role in the inflammation process and insulin resistance. Arkan et al. [36], for example, showed that deletion of
IKK $\beta$, required for the activation of $\mathrm{NF \kappa B}$, in myeloid precursor cells protected animals from diet-induced obesityrelated insulin resistance.

To investigate the acute effect of insulin on the low-grade pro-inflammatory profile in type 2 diabetic patients at constant glucose concentrations, plasma inflammation parameters were analysed before and after the hyperinsulinemic-euglycemic clamp. Results, however, were not conclusive. MCP1 level decreased in both diabetic and control subjects, IL6 level increased only in control subjects, while hsCRP and TNFa levels did not significantly change. The reduced MCP1 level after insulin stimulation can, however, also be an indirect effect of insulin and explained for example by the insulin-mediated reduction in FFA [37]. The causal role of IL6 in the development of insulin resistance and type 2 diabetes is not clear. Infusion with a physiological concentration of IL6 in humans increased the uptake of glucose in subcutaneous adipose tissue in vivo [38]. On the other hand, IL6 levels are increased in type 2 diabetic subjects. Like in our study, Krogh-Madsen et al. found an increase in plasma IL6 concentrations during a hyperinsulinemic-euglycemic clamp in healthy human males [39]. This increase was accompanied by an elevated insulin-stimulated increase in IL6 gene expression in adipose tissue. Also, they found no change in plasma concentrations of $\mathrm{TNF} \alpha$, which expression was increased in adipose tissue and reduced in muscle tissue [39]. The reason that we did not find a reduction in hsCRP concentration may have been due to the relative short time of insulin infusion in our study, as previous studies demonstrated decreased hsCRP concentrations after 10 or more hours of insulin infusion [40-42]. It also needs to be mentioned that during the hyperinsulinemiceuglycemic clamp, not only insulin infusion can exerts biological effects, but also the amount of glucose infused to maintain euglycemia [43]. However, Dandona et al. have demonstrated an acute anti-inflammatory effect of insulin infusion at a physiological concentration, infusing insulin (2.0-2.5 IU/h) - dextrose $(5 \%)$ and in obese nondiabetic subjects, while maintaining glucose levels as close to basal levels as possible [41]. This anti-inflammatory effect was reflected by reduced intranuclear levels of $\mathrm{NF \kappa \textrm {B }}$, increased $\mathrm{I} \kappa \mathrm{B}$, decreased ROS generation and decreased p47phox subunit in PBMCs, decreased plasma intracellular adhesion molecule 1, plasminogen inhibitor 1 and MCP1 concentrations [41]. Infusion with only dextrose or saline had no effects on these parameters [41]. Taken together, a supra-physiological increase in insulin concentration does not per se contribute to the disturbances in inflammatory markers in type 2 diabetic patients. 


\section{Conclusion}

In conclusion, 8 weeks of rosiglitazone treatment $(2 \times 4$ $\mathrm{mg} / \mathrm{d}$ ) resulted in improved insulin sensitivity and lipid profile and reduced concentrations of plasma inflammatory markers (MCP1 and hsCRP) in type 2 diabetic patients. Furthermore, plasma inflammatory parameters did not change consistently during the clamp in both diabetic and control patients, which does not suggest that high insulin levels contribute to the proinflammatory state in type 2 diabetic patients. Finally, the anti-inflammatory effect of rosiglitazone is not reflected by changes in NFKB and PPAR $\gamma$ target genes in PBMCs in vivo.

\section{Competing interests}

The authors declare that they have no competing interests.

\section{Authors' contributions}

All authors contributed to the design, execution, and analysis of this study and writing the manuscript. All authors read and approved the final manuscript.

\section{Additional material}

\section{Additional file 1}

$84 N F \kappa B$-related genes measured with the NFKB RT $T^{2}$ Profiler PCR array. The gene table provided represents the $84 N F \kappa B$-related genes measured with the NFKB RT2 Profiler PCR array

Click here for file

[http://www.biomedcentral.com/content/supplementary/14726823-9-8-S1.pdf]

\section{Acknowledgements}

This study was funded by the Nutrigenomics Consortium (NGC) of Top Institute Food and Nutrition (TIFN), the Dutch BSIK fund, and GlaxoSmithKline. We would like to acknowledge Martine Hulsbosch from NGC of TIFN for the analysis of plasma lipids and her help with the immunoassays and gene expression analysis.

\section{References}

I. Delerive P, Fruchart J, Staels B: Peroxisome proliferator-activated receptors in inflammation control. I Endocrinol 2001 1 69:453-459.

2. Haffner SM, Greenberg AS, Weston WM, Chen H, Williams K, Freed $\mathrm{MI}$ : Effect of rosiglitazone treatment on nontraditional markers of cardiovascular disease in patients with type 2 diabetes mellitus. Circulation 2002, 106:679-684.

3. Mohanty P, Aljada A, Ghanim H, Hofmeyer D, Tripathy D, Syed T, AlHaddad W, Dhindsa S, Dandona P: Evidence for a potent antiinflammatory effect of rosiglitazone. J Clin Endocrinol Metab 2004 89(6):2728-35.

4. Hayden MS, West AP, Ghosh S: NF-kappaB and the immune response. Oncogene 2006, 25(5 I):6758-80.

5. RK Semple, Chatterjee VK, O'Rahilly S: PPAR gamma and human metabolic disease. J Clin Invest 2006, I I 6(3):58I-9.

6. Jiang C, Ting A, Seed B: PPAR- $\gamma$ agonists inhibit production of monocyte inflammatory cytokines. Nature 1998 , 39 I(6662):82-86

7. Krogh-Madsen R, Moller K, Dela F, Kronborg G, Jauffred S, Pedersen $B K$ : Effect of hyperglycemia and hyperinsulinemia on the response of IL-6, TNF-alpha, and FFAs to low-dose endotox- emia in humans. Am I Physiol Endocrinol Metab 2004, 286(5):E766-72.

8. Mensink M, Hesselink MK, Russell AP, Schaart G, Sels JP, Schrauwen $P$ : Improved skeletal muscle oxidative enzyme activity and restoration of PGC-I alpha and PPARbeta/delta gene expression upon rosiglitazone treatment in obese patients with type 2 diabetes mellitus. Int J Obes (Lond) 2007, 3 I (8): | 302- I 3 I 0.

9. Schrauwen P, Mensink M, Schaart G, Moonen-Kornips E, Sels JP, Blaak EE, Russell AP, Hesselink MK: Reduced skeletal muscle uncoupling protein-3 content in prediabetic subjects and type 2 diabetic patients: restoration by rosiglitazone treatment. J Clin Endocrinol Metab 2006, 91 (4): I520-5.

10. Friedewald WT, Levy RI, Fredrickson DS: Estimation of the concentration of low-density lipoprotein cholesterol in plasma, without use of the preparative ultracentrifuge. Clin Chem 1972, I 8(6):499-502.

II. Margarson M, Soni N: Plasma volume measurement in septic patients using an albumin dilution technique: comparison with the standard radio-labelled albumin method. Intensive Care Med 2005, 3 I:289-295.

12. Heinaniemi M, Uski JO, Degenhardt T, Carlberg C: Meta-analysis of primary target genes of peroxisome proliferator-activated receptors. Genome Biol 2007, 8(7):RI47.

13. Schoonjans K, Peinado-Onsurbe J, Lefebvre AM, Heyman RA, Briggs M, Deeb S, Staels B, Auwerx J: PPARalpha and PPARgamma activators direct a distinct tissue-specific transcriptional response via a PPRE in the lipoprotein lipase gene. Embo J 1996, I 5( I 9):5336-48.

14. Tontonoz P, Nagy L, Alvarez JG, Thomazy VA, Evans RM: PPARgamma promotes monocyte/macrophage differentiation and uptake of oxidized LDL. Cell 1998, 93(2):24I-52

15. Dhindsa S, Tripathy D, Sanalkumar N, Ravishankar S, Ghanim H, Aljada $A$, Dandona $P$ : Free fatty acid-induced insulin resistance in the obese is not prevented by rosiglitazone treatment. Clin Endocrinol Metab 2005, 90(9):5058-63.

16. van Wijk JP, de Koning EJ, Martens EP, Rabelink TJ: Thiazolidinediones and blood lipids in type 2 diabetes. Arterioscler Thromb Vasc Biol 2003, 23(10): I 744-9.

17. Chu JW, Abbasi F, Lamendola C, McLaughlin T, Reaven GM, Tsao PS: Effect of rosiglitazone treatment on circulating vascular and inflammatory markers in insulin-resistant subjects. Diab Vasc Dis Res 2005, 2(I):37-4I.

18. Hetzel J, Balletshofer B, Rittig K, Walcher D, Kratzer W, Hombach V, Haring HU, Koenig W, Marx N: Rapid effects of rosiglitazone treatment on endothelial function and inflammatory biomarkers. Arterioscler Thromb Vasc Biol 2005, 25(9): I804-9.

19. Popa C, Netea MG, van Riel PL, Meer JW van der, Stalenhoef AF: The role of TNF-\{alpha\} in chronic inflammatory conditions, intermediary metabolism, and cardiovascular risk. J Lipid Res 2007, 48(4):75I-62.

20. Pradhan AD, Manson JE, Rifai N, Buring JE, Ridker PM: C-reactive protein, interleukin 6 , and risk of developing type 2 diabetes mellitus. JAMA 200I, 286(3):327-34.

21. Marx N, Imhof A, Froehlich J, Siam L, Ittner J, Wierse G, Schmidt A, Maerz W, Hombach V, Koenig W: Effect of rosiglitazone treatment on soluble CD40L in patients with type 2 diabetes and coronary artery disease. Circulation 2003, I07( I 5): I 954-7.

22. Varo N, Vicent D, Libby $P$, Nuzzo R, Calle-Pascual AL, Bernal MR, Fernandez-Cruz A, Veves A, Jarolim P, Varo J], Goldfine A, Horton E, Schonbeck U: Elevated plasma levels of the atherogenic mediator soluble CD40 ligand in diabetic patients: a novel target of thiazolidinediones. Circulation 2003, I 07(2 I):2664-9.

23. Goldstein BJ, Weissman PN, Wooddell MJ, Waterhouse BR, Cobitz $A R$ : Reductions in biomarkers of cardiovascular risk in type 2 diabetes with rosiglitazone added to metformin compared with dose escalation of metformin: an EMPIRE trial substudy. Curr Med Res Opin 2006, 22(9): I7।5-23.

24. Agrawal A, Cha-Molstad H, Samols D, Kushner I: Overexpressed nuclear factor-kappaB can participate in endogenous $C$ reactive protein induction, and enhances the effects of $C$ / EBPbeta and signal transducer and activator of transcription-3. Immunology 2003, I 08(4):539-47.

25. Teferedegne B, Green MR, Guo Z, Boss JM: Mechanism of action of a distal NF-kappaB-dependent enhancer. Mol Cell Biol 2006, 26(I 5):5759-70. 
26. Ghosh S, May MJ, Kopp EB: NF-kappa B and Rel proteins: evolutionarily conserved mediators of immune responses. Annu Rev Immunol 1998, 16:225-60.

27. Saklatvala J, Guesdon F: Interleukin I and tumor necrosis factor signal transduction mechanisms: potential targets for pharmacological control of inflammation. J Rheumatol Suppl 1992, 32:65-9. discussion 69-70.

28. Takayanagi H, Ogasawara K, Hida S, Chiba T, Murata S, Sato K, Takaoka A, Yokochi T, Oda H, Tanaka K, Nakamura K, Taniguchi T: Tcell-mediated regulation of osteoclastogenesis by signalling cross-talk between RANKL and IFN-gamma. Nature 2000, 408(68I2):600-605.

29. Sun SC, Ganchi PA, Ballard DW, Greene WC: NF-kappa B controls expression of inhibitor I kappa $B$ alpha: evidence for an inducible autoregulatory pathway. Science 1993 259(5 I 03): $1912-5$.

30. Ghanim H, Garg R, Aljada A, Mohanty P, Kumbkarni Y, Assian E, Hamouda W, Dandona P: Suppression of nuclear factor-kappaB and stimulation of inhibitor kappaB by troglitazone: evidence for an anti-inflammatory effect and a potential antiatherosclerotic effect in the obese. J Clin Endocrinol Metab 200I, 86(3): $1306-12$.

31. Chawla A, Barak Y, Nagy L, Liao D, Tontonoz P, Evans R: PPAR-g dependent and independent effects on macrophage gene expression in lipid metabolism and inflammation. Nature Medicine 200I, 7(I):48-52.

32. Moore KJ, Rosen ED, Fitzgerald ML, Randow F, Andersson LP, Altshuler D, Milstone DS, Mortensen RM, Spiegelman BM, Freeman MW: The role of PPAR-gamma in macrophage differentiation and cholesterol uptake. Nat Med 200I, 7(I):4I-7.

33. Li L, Beauchamp MC, Renier G: Peroxisome proliferator-activated receptor alpha and gamma agonists upregulate human macrophage lipoprotein lipase expression. Atherosclerosis 2002, 165(I): $101-10$

34. Bouhlel M, Derudas B, Rigamonti AE, Dievart R, Brozek J, Haulon S, Zawadski C, Jude B, Torpier G, Marx N, Staels B, Chinetti G: PPARg activation primes human monocytes into alternative $M 2$ macrophages with anti-inflammatory properties. Cell Metab 2007, 6: | $37-143$

35. Hong G, Davis B, Khatoon N, Baker SF, Brown J: PPAR gammadependent anti-inflammatory action of rosiglitazone in human monocytes: suppression of TNF alpha secretion is not mediated by PTEN regulation. Biochem Biophys Res Commun 2003, 303(3):782-7.

36. Arkan MC, Hevener AL, Greten FR, Maeda S, Li ZW, Long JM, Wynshaw-Boris A, Poli G, Olefsky J, Karin M: IKK-beta links inflammation to obesity-induced insulin resistance. Nat Med 2005, II(2): $191-8$

37. Tripathy D, Mohanty P, Dhindsa S, Syed T, Ghanim H, Aljada A, Dandona $P$ : Elevation of free fatty acids induces inflammation and impairs vascular reactivity in healthy subjects. Diabetes 2003 , 52(1 2):2882-7.

38. Lyngso D, Simonsen L, Bulow J: Metabolic effects of interleukin6 in human splanchnic and adipose tissue. J Physiol 2002 543(Pt I):379-86.

39. Krogh-Madsen R, Plomgaard P, Keller P, Keller C, Pedersen BK: Insulin stimulates interleukin-6 and tumor necrosis factor-alpha gene expression in human subcutaneous adipose tissue. Am J Physiol Endocrinol Metab 2004, 286(2):E234-8.

40. Chaudhuri A, Janicke D, Wilson MF, Tripathy D, Garg R, Bandyopadhyay A, Calieri J, Hoffmeyer D, Syed T, Ghanim H, Aljada A, Dandona $P$ : Anti-inflammatory and profibrinolytic effect of insulin in acute ST-segment-elevation myocardial infarction. Circulation 2004, 109(7):849-54.

4I. Dandona P, Aljada A, Mohanty P, Ghanim H, Hamouda W, Assian E, Ahmad S: Insulin inhibits intranuclear nuclear factor kappaB and stimulates IkappaB in mononuclear cells in obese subjects: evidence for an anti-inflammatory effect? J Clin Endocrinol Metab 200I, 86(7):3257-65.

42. Wong VW, McLean M, Boyages SC, Cheung NW: C-reactive protein levels following acute myocardial infarction: effect of insulin infusion and tight glycemic control. Diabetes Care 2004, 27( I 2):297|-3.

43. Mohanty P, Hamouda W, Garg R, Aljada A, Ghanim H, Dandona P: Glucose challenge stimulates reactive oxygen species (ROS) generation by leucocytes. I Clin Endocrinol Metab 2000, 85(8):2970-3.

\section{Pre-publication history}

The pre-publication history for this paper can be accessed here:

http://www.biomedcentral.com/1472-6823/9/8/prepub
Publish with Bio Med Central and every scientist can read your work free of charge

"BioMed Central will be the most significant development for disseminating the results of biomedical research in our lifetime. "

Sir Paul Nurse, Cancer Research UK

Your research papers will be:

- available free of charge to the entire biomedical community

- peer reviewed and published immediately upon acceptance

- cited in PubMed and archived on PubMed Central

- yours - you keep the copyright 